\title{
Intoxicant use in the prehistoric Caribbean with particular reference to spouted ceramic inhaling bowls.
}

\author{
Quetta Kaye \\ Institute of Archaeology, UCL
}

\section{Introduction}

The New World is unusually rich in hallucinogenic plants (Schultes and Hofmann 1980: 22). Ethnological research has well documented the ritual use of these substances by the inhabitants of the South American tropical rainforests (Wassen 1965). While archaeological research has tended to concentrate on the great ancient American civilisations of the Incas, Aztecs and Maya, which also reveal ritual usage of mind altering substances (Furst and Coe 1977; Coe 1988: 222-235; Bruhns 1994: 73-74, 215-216, 391), no comparable study or research has been undertaken for the pre-Columbian inhabitants of the Caribbean islands.

This omission occurs despite accounts from early Spanish chroniclers (the cronistas) which detail the central role ritual intoxication played in the islanders' lives (Bourne 1906: 4; Keen 1959:167; Arrom 1992: 26, 280). Of course, the Spanish chroniclers were neither unbiased in their accounts nor necessarily able to understand all that they saw. Christopher Columbus is known to have taken with him a Catalan friar, Ramon Pané, on his second voyage in 1493. He commanded Pané to live among the Indians to "learn their language and collect all their ceremonies and antiquities" (Bourne 1906: 4). It is from accounts like this and from the life of Christopher Columbus written by his son, Fernando (which incorporated parts of Pané's Relación), that we can read of the world of the fast disappearing Indians, their animistic religious beliefs and the first descriptions of the ritual use of intoxicants in the cohoba ceremony.

It should be noted that within an astonishingly short time of their encounter with representatives of the Old World the indigenous peoples of the Caribbean islands were all but wiped out, although various biological traits of these peoples survive, initially through the intermarriage of native women with Spanish men, $40 \%$ by the census of 1514 (Rouse 1992: 158). A scattering of “Caribs” also still occupy some remote areas of St Vincent and the Carib Territory of Dominica is home to an albeit mixed-blood population of some 3,000 people with a claim to Carib ancestry (Honychurch 1995: 161).

The identification and study of nearly three hundred items of paraphernalia relating to intoxicant use and its associated ritual reveals these objects can be seen as reflections not only of ideological concepts, belief systems and social relations, but that they were also a major tool for constructing and transforming peoples' perception of the world. A study of this surviving paraphernalia and, in particular, spouted ceramic inhaling bowls, enables us also to make comparison with material culture from the circum-Caribbean mainland.

Papers from the Institute of Archaeology 10 (1999): 55-73 

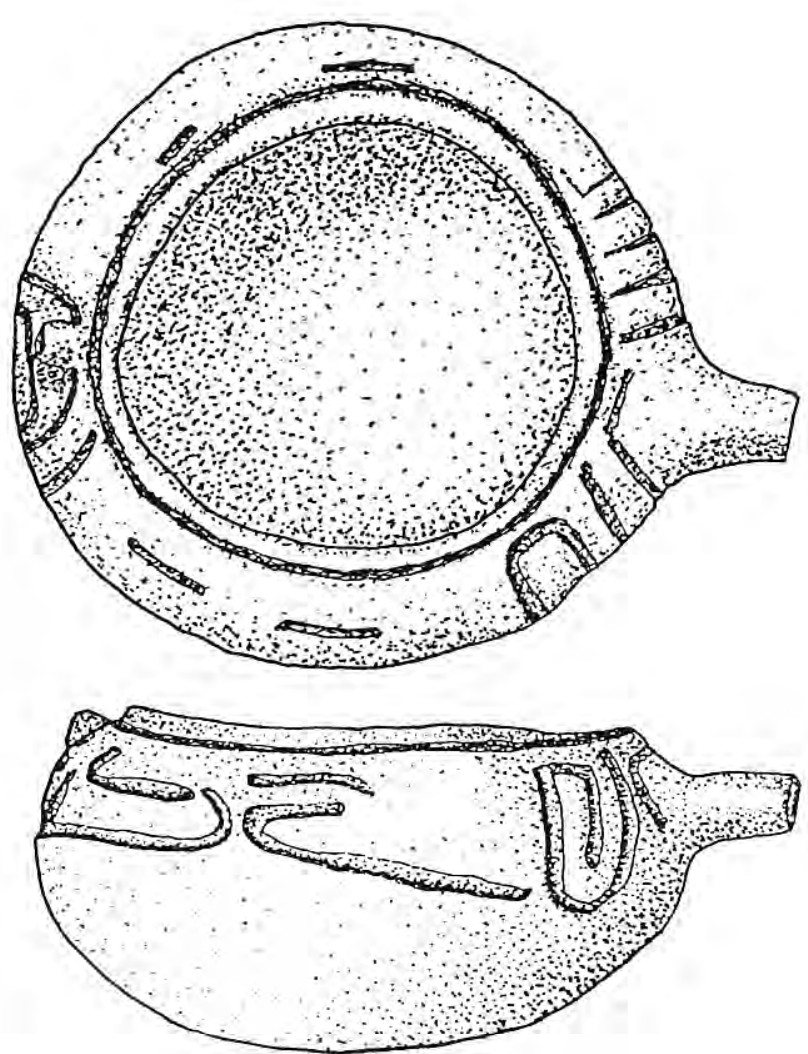

Cm

Figure 1a/b Single spouted inhaling bowl - Dominican Republic (Museo del Hombre Dominicano)

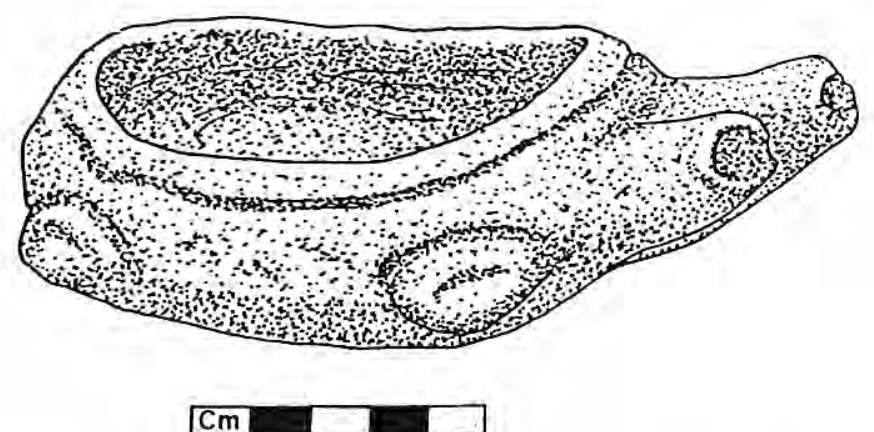

Figure 2 Bifurcated inhaling bowl - Trinidad (after Museum fuer Voelkerkunde, Basel, IV 241) 
Basel, IV 241)

Made in wood, stone, bone, ceramic and shell, a range of artefacts associated with the use of intoxicants has survived, despite the ravages of time, the effect of the subtropical climate on organic materials and the systematic destruction of "idolatrous" artefacts by the early colonisers. The collections which are available for study today, however, are largely without provenance. They are, in many cases, the result of surface collection and donation predominantly since the $19^{\text {th }}$ century rather than systematic archaeological excavation. Such collections therefore reflect biases in what has been considered collectable over the years - usually their "artistic" quality. They also reflect the relative local intensity of research interest. Due to the complex interactions involved in the colonisation of the Caribbean islands, artefacts have been scattered to collections in many different parts of the world. To this day many islands do not have legislation to protect their archaeology nor archaeological research facilities.

\section{Background to Caribbean prehistory}

Archaeological evidence supports pre-ceramic occupation of the Caribbean islands from c. 5,000 BC (Dacal Maure and Rivero de la Calle 1996: 14; Wilson 1997: 4-7). Archaeological evidence also confirms that around the last centuries BC early agriculturalists migrated from the Orinoco delta of Venezuela and travelled the South Equatorial current to the islands in their canoes, bringing their ceramic tradition with them, originating from the type site of Saladero. These Caribbean Saladoid ceramics continued to share strong similarities with those from the mainland well into the first centuries $\mathrm{AD}$, to the point that it has been suggested that "we may be able to connect a sherd from Venezuela directly to another from Martinique” (Allaire 1997: 23).

Alternative theories of the peopling of the islands, however, point to evidence for early inter-American contact, possibly through a network of maritime trade between Ecuador, the north coast of South America and Mesoamerica c. 1500 and 600 BC and between Ecuador and Costa Rica from 100 BC to 600 AD (Paulsen 1977: 141160). This contact is emphasised by the resemblance of the very early shaft-andchamber tombs, whose distribution is limited almost entirely to the Jalisco, Colima and Nayarit states of western Mexico, to those of the Cauca Valley and central Andes of Colombia. Small single and bifurcated plain, round bowled, ceramic inhaling vessels from this area of west Mexico (some deriving from these shaft-andchamber tombs) are very similar to vessels found in Costa Rica and also echo the forms of those found across the Caribbean islands (Figs. 1 and 2). Other parallels include red-on-buff painting and distinctive ceramic stirrup-spout vessels which occur at Capacha, Colima, west Mexico dating from c. 1450 BC whose first appearance is known in the Ecuadorian Machalilla phase, c. 1500-1000 BC (Porter Weaver 1981: 496; Anawalt 1998: 239; Furst 1998: 169-189). It has been suggested that this represents a well-established two-way trade in precious goods by south American shaman (Furst 1989: 189).

Later Mesoamerican similarities occur with the finding of massive sculpted stone collars used in the playing of a ball game on central plazas or ball courts, mainly in the Greater Antilles, similar to that noted on the mainland in later contact period reports (Fewkes 1907: 167; Willey 1971: 371). However, support for the theory of 
Mesoamerican cultural contact is weakened by the lack of monumental architecture in the Caribbean and an absence of trading goods or other evidence of regular contact (Alegria 1951: 348).

Relatively recent archaeological study has produced evidence, confirmed by the ethnohistorical records, which indicates the islands were generally at what is considered to be a pre-literate "Formative" stage of development when first contacted by Europeans. That is, the islanders lived in wooden structures in large permanent groups or villages, with knowledge of pottery and agriculture, under the rule of a chief (cacique) who was usually male but with instances of female cacicas also known (Rouse 1948: 507-546; Sauer 1966: 60).

Until recently there was general support for the cronistas' reports that the population as found in 1492 was the result of successive waves of immigrants, each one supplanting the other and of culture change only in response to external pressure. Recent works point out inconsistencies in the contact period reports in this respect and lack of archaeological corroboration. Various alternative theories seeking to explain the movements of peoples through the island chains have now been postulated (Hulme 1986; Keegan and Diamond 1989; Davis and Goodwin 1989).

\section{The cohoba ceremony}

Although Christopher Columbus wrote in the diary of his first voyage that he believed the "Indians" had no religious beliefs, nor were they idolators, Fernando Columbus relates a passage in which his father later described the following: "The kings.... have a house apart from the village, in which there is nothing except some wooden images carved in relief which are called cemis nor is there anything done in such a house for any other object or service except for these cemis. In this house they have a finely wrought table, round like a wooden dish in which is some powder which is placed by them on the heads of these cemis in performing a certain ceremony; then, with a cane that has two branches, which they place in their nostrils, they snuff up this dust. The words that they say none of our people understand. With this powder they lose consciousness and become like drunken men..." (Bourne 1906: 4). Ramon Pané describes the reaction to the inhalation of the cohoba as "the house appears to be turned upside down and the people to be walking with their feet in the air" (Keen 1959: 167). A lucid fifteenth century description of hallucinatory disorientation.

Far from having no religion or idolatry, later observation had revealed the Caribbean islanders' religion was fundamental to their way of life, having many traits in common with the mainland of South America, with shaman occupying a central position in their society. As in all known Amerindian societies, the shamanistic function was to heal, divine the future, bedevil enemies, commune with ancestors and make contact with the gods. The religion was animistic, based on the spirits of natural phenomena, on "plant teachers" and of the departed dead, which were given residence by the manufacture of cemis (Oliver 1997: 140-153; Siegel 1997: 106111). Central to their beliefs was the power derived from the inhalation of highly hallucinogenic powders, the cohoba, taken ceremonially using specific paraphernalia. 


\section{The paraphernalia of intoxicant use}

In describing the use of cohoba the cronistas identified certain of the paraphernalia used in the ceremony. The range of artefacts specifically mentioned includes vomit spatulas, duhos (small ceremonial benches), cemis or idols, from the canopied heads of which the powder was taken, and the inhaling tubes through which it was snuffed. However, no mention was made by the cronistas of inhalation through the ceramic inhaling bowls referred to earlier (Figs. 1-2) and there is, therefore, no knowledge of the circumstances in which these were used. There is, however, general acceptance of these bifurcated vessels as inhaling devices (Wassen 1965: 25) and practical experiment by the writer can confirm their efficacy as a means of delivering snuff to the sensitive nasal membranes.

Ritual purification through fasting and self-induced vomiting was a pre-requisite to participation in the cohoba ceremony. "In order to be purged in the way most agreeable to the deity, they put in their throat as far as the epiglottis, or even as far as the uvula, the spatula which every one carries always in the hand...they vomited and evacuated the stomach until there was nothing left" (Peter Martyr quoted in Alegria 1981: 24). Carved from bone, shell, wood and with a few examples in stone, some spatulas also retain traces of inlay with gold and semi-precious stones. Figure 9 is an example of a decorative double bladed bone vomit spatula.

Highly prized ceremonial seats (duhos) were used for participation in the ceremony. "He took his cohoba sniffing through the nose... sitting down on little stools, well engraved, called duhos...” (Las Casas in Veloz Maggiolo 1972: 189). Also constructed from wood or stone and found, in some instances, with gold inlay still in place, the seats take a high backed (Fig. 3) or a low backed form (Fig. 4). That these seats were held in high esteem is inferred by the restriction of their use to an élite on ceremonial occasions, as mentioned above. That Bartholomé Columbus was honoured with their presentation as gifts for him to take back to Spain specially chosen by the cacica Anacaona from her warehouse in Haiti (Sauer 1966: 60) could be seen as incorporating the Spanish king into the élite group and ritual hierarchy of Haitian society.

Contemporary reference was made to forked tubes (Figs. 5 and 6) being used to snuff up the intoxicating material from a dish on the head of cemi or idol. These free standing cemi figures were manufactured from single blocks of either wood or stone, with an integral disc or canopy resting either directly on top of the head of the figure, defined as the "platter" type (Fig. 7) or supported by a projecting extension, the "extension" type (Fig. 8 - in this example lacking the dished canopy).

As mentioned earlier, the majority of these paraphernalia have been collected as a result of surface finds. Study of the contexts of find sites (where these are known)

show that a high proportion of the wooden artefacts have survived the sub-tropical climate as a result of being secreted deep within the micro-environment of caves. 


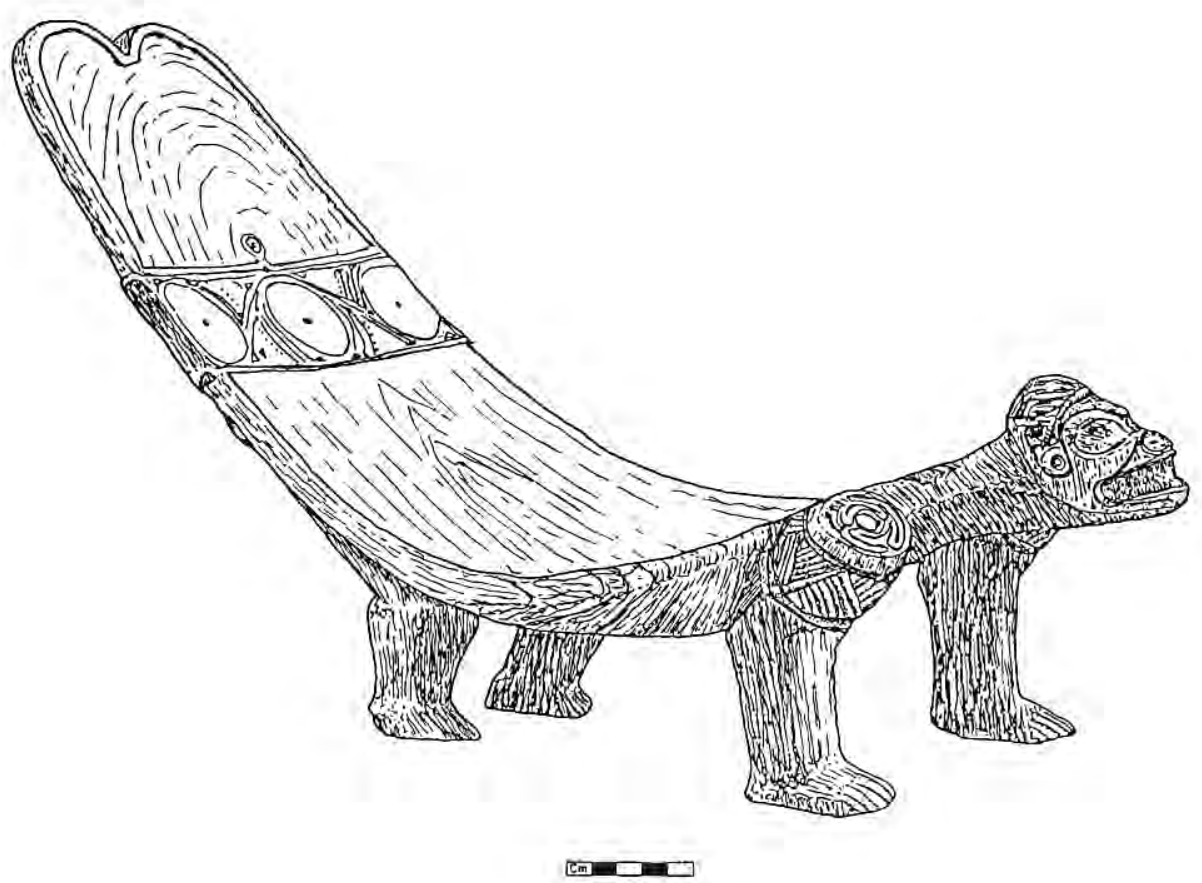

Figure 3 Duho - Haiti (after Kerchache 1994: 42-45)

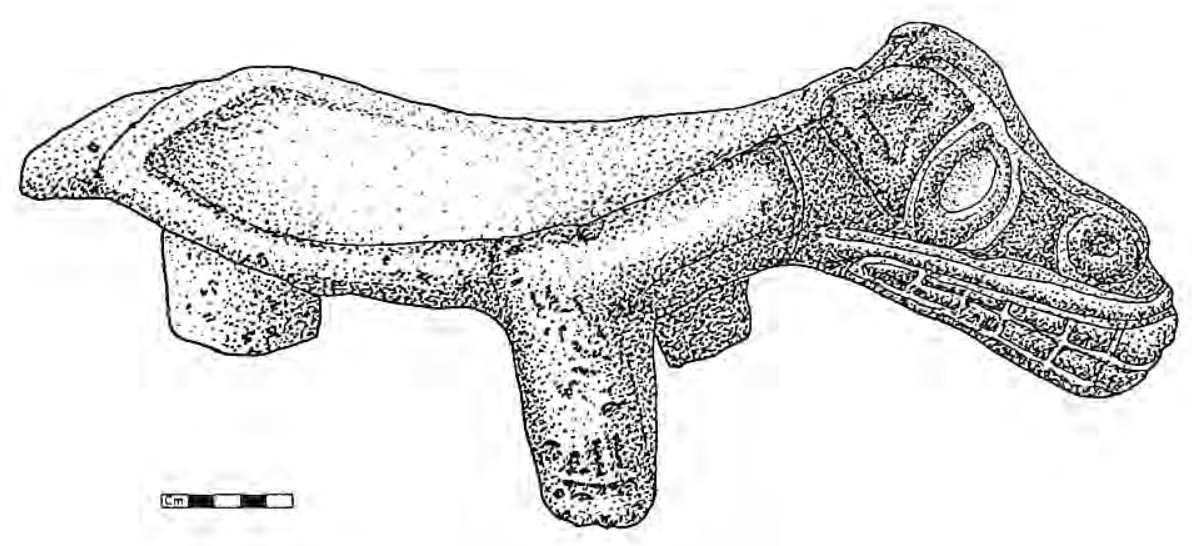

Figure 4 Duho - Puerto Rico (Museo del Indio, San Juan) 

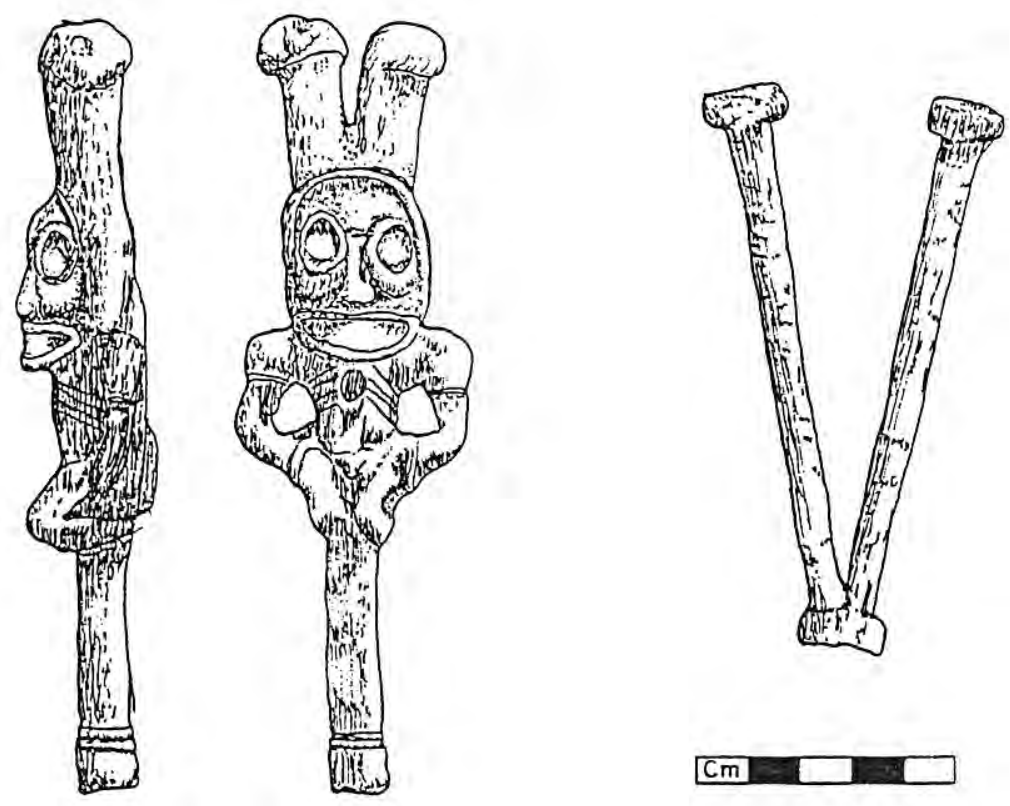

Figures 5 a/b and 6 Bifurcated inhaling tubes: Dominican Republic (after Kerchache 1994: 84) and Puerto Rico (after Rainey 1940: 73)

Caves are known to have had a particular significance in the religious or supernatural mythology of the Caribbean where they were thought to be the dwelling place of spirits, as well as the birthplace of men. This significance is endorsed by the presence of cave art, in the form of petroglyphs and paintings, which occur throughout the Antilles (Dubelaar 1995). Columbus referred to the various ways in which a cacique could be buried, which included burial in caves "with bread and a calabash full of water above his head..." (Keen 1959: 155). My research suggests, therefore, that the duhos, idols, vomit spatulas and inhaling tubes recovered from cave sites could be seen as examples of the extension of ritual rather than an attempt at preservation from discovery.

In a limited number of cases vomit spatulas have also been recovered in association with burials in middens in Puerto Rico, together with polished bone tubes (Rainey 1940: 73-98). They have also been found alongside bodies in burials in the Dominican Republic (Veloz Maggiolo 1977b: 81) and in a "ritual context" from Tortola, Virgin Islands (Drewett 1998: 6-7). Unlike the other artefact types, ceramic inhaling bowls have not been recovered from caves, but, in addition to surface finds, have been excavated from middens in association with burials (Narganes Storde 1997: pers. comm.). The association of vomit spatulas and inhaling bowls with open access locations (domestic midden burials) rather than the spiritual but controlled access of caves gives an indication of changes in social hierarchy and use of ritual activity. 


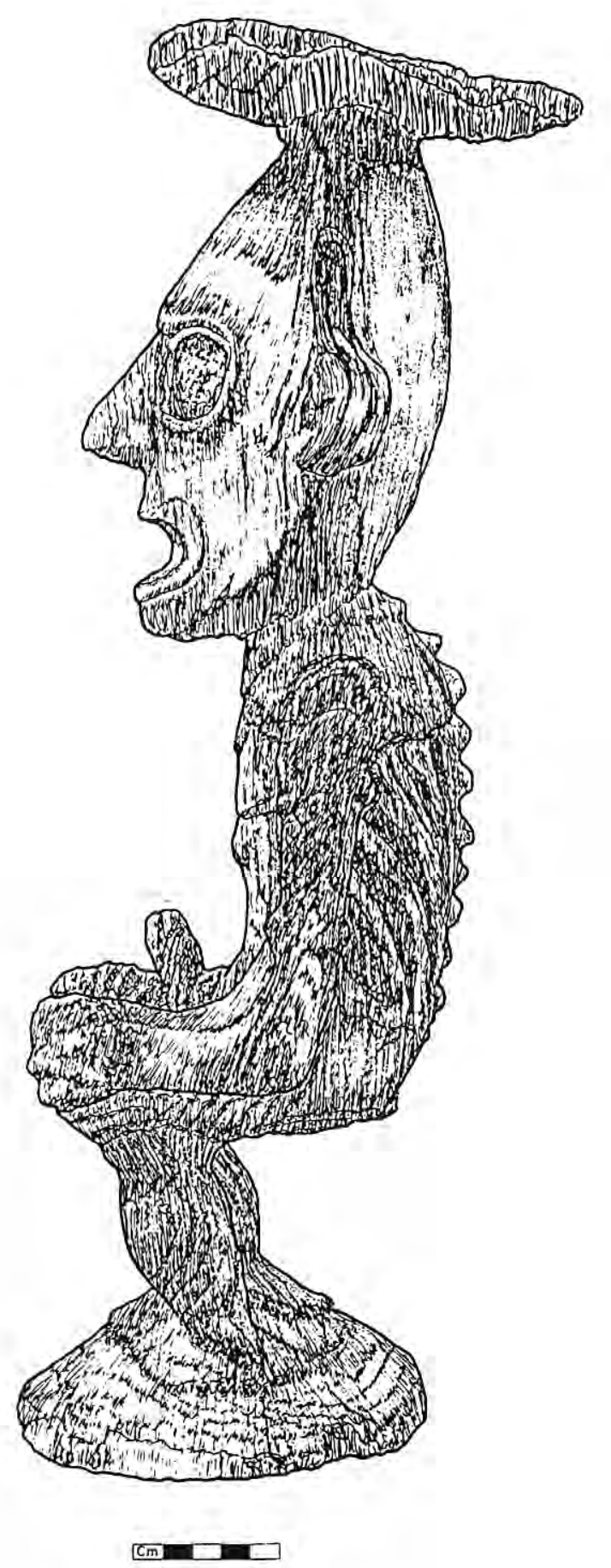

Figure 7 Idol - Dominican Republic (after Kerchache 1994: 110-113) 


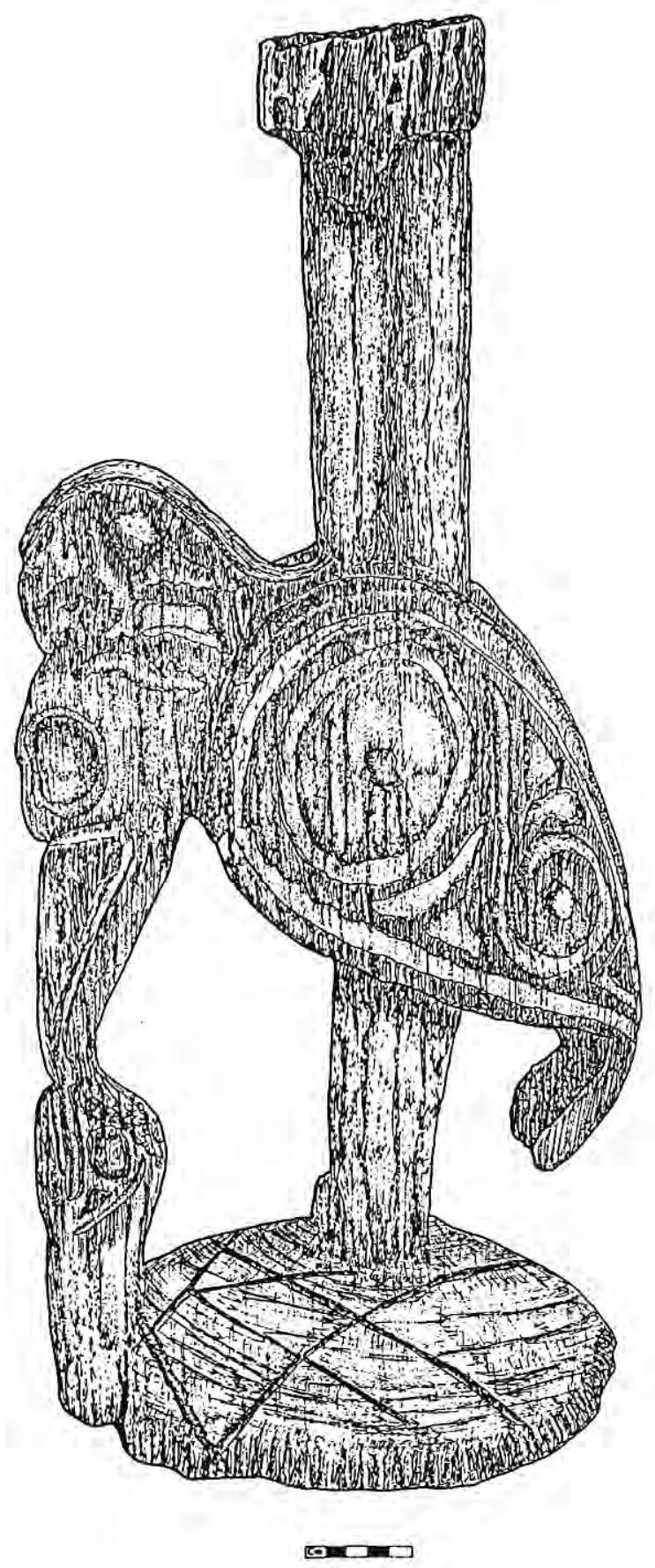

Figure 8 Idol - Dominican Republic (British Museum, AmMl.168) 


\section{Designs and forms}

Found in anthropomorphic, zoomorphic and anthropo/zoomorphic as well as plain forms, the study of this paraphernalia reveals frequent use of artistry and imagery far in excess of functional needs. When applied to otherwise functional objects, this enables a link to be made to the known mythology and belief systems of the islanders. It also provides data for a consideration of changes in socio/religious organisation. Craft specialisation and social complexity are inferred when activities exceed the scale of single households and autonomous communities (Keegan 1992: 10).

In construction of an artefact the choice of stone rather than wood may not appear to us to have any special significance. Within an animistic society, however, where the natural world is thought to be spiritually active, the choice of which material is used is likely to be very significant, as with the use of certain animal bones for vomit spatulas and inhaling tubes. Similarly, in terms of the considerable differences in time and labour invested in the creation of a stone image, as opposed to a wooden one, the choice of material becomes significant indeed, with a need for superior technical ability and therefore greater value being added to the stone artefact.

The sixty-seven anthropomorphic forms studied (a majority of the idols and vomit spatulas) show these are invariably solitary and male, as shown in Figure 7. Only one idol of very complicated construction (from the Dominican Republic), has the representation of two human figures together. These figures, seated side by side on a duho with their feet raised up onto the seat, are thought to be one representation of the duality which was elemental to Taino mythology. There are very few depictions of female forms, although pre-Columbian female figures are given iconographic representation, notably on late period petroglyphs at the Caguana site in Puerto Rico (Roe 1993: 637; Oliver 1997: 140-153).

The human representations are stylistically similar. Invariably naked and, where shown, the phallus is always erect, interpreted as a representation of the sexuality which shaman were denied in life. The posture is invariably the ritual one of bent knees, either crouched or squatting (occasionally contorted); the figure is never engaged in any activity. The body appears emaciated with exposed ribs and vertebrae, the physical representations of self-denial and fasting - deprivation producing susceptibility to hallucinations. Bumps protrude on the ankles and wrists, considered as doorways through which spirit influences can enter and leave the body (Roe 1993: 643).

Body decoration consists of geometrically patterned armbands, leg bands and patterned head-dress or headband. The facial features are described almost identically in all cases. Foreheads are flattened, eyes are invariably encircled, mouths are grimacing. In almost all instances emphasis is given to certain body parts so that they seem to have emerged from the same tradition or workshop.

Certain adornments can be interpreted as reflecting practice at the time of contact, confirmed by the contemporary accounts. Columbus reported naked men wearing feathered head-dresses with "painting to make more hideous around the eyes" (Fewkes 1907: 220). Facial disfigurement and staining with black, white and arnotto 
(an orange-red dye) are also quoted from Rochefort 1665 by Roach (1935: 137-148). Lines from the eyes or "tear stains" have also been noted as depicting associations with watering eyes and mucus flow which are observed reactions to the inhalation of hallucinogenic powders among South American tribes (Wassen 1965: 19). Also reflecting contemporary descriptions of limb binding (Alegria 1995: 296-298) are the bands of patterning on the calves and arms of most anthropomorphic figures.

The crouched or squatting posture (shown in Figure 7) taken by the majority of the figures, can be seen as the shamanistic pose after use of hallucinogens among the modern Tukano of Colombia (Reichel-Dolmatoff 1988: 44, 45). It is also the pose adopted by shaman performing a curing ritual seen in the prolific Costa Rican sukia figures (Jones 1991: 33). A similar pose is also reported as used in the ceramic figures from pre-Hispanic Colombia - although without indication of a bench, which is not commonly rendered until after $500 \mathrm{AD}$ (Labbé 1986: 44).

Zoomorphic forms, perhaps the metamorphosed form of the shaman during the hallucinogenic ritual, include representations of bats (Fig. 9), birds, dogs (Fig. 4), fish, reptiles, turtles and combinations of bird and turtle (Fig. 8). Some zoomorphs are adorned with decorative body patterning which, where it occurs, conforms to the customary geometric patterns of circles, triangles and parallel lines (Fig. 8). Birds, associated with shamanistic ecstatic flight, are the zoomorphic symbol most frequently found with iconographic representations. Turtles, one of the largest animals available to the prehistoric islanders, also feature in their creation myth, in which cohoba mucus spat onto the back of one of the two pairs of founding twins of Taino society transforms into a turtle from which "the Turtle woman (bride) emerges" (Roe 1997: 153). Figure 8 shows the support for the cohoba canopy emerging from the back of the turtle, passing through the body of the symbolically decorated bird whose beak also merges into that of the turtle.

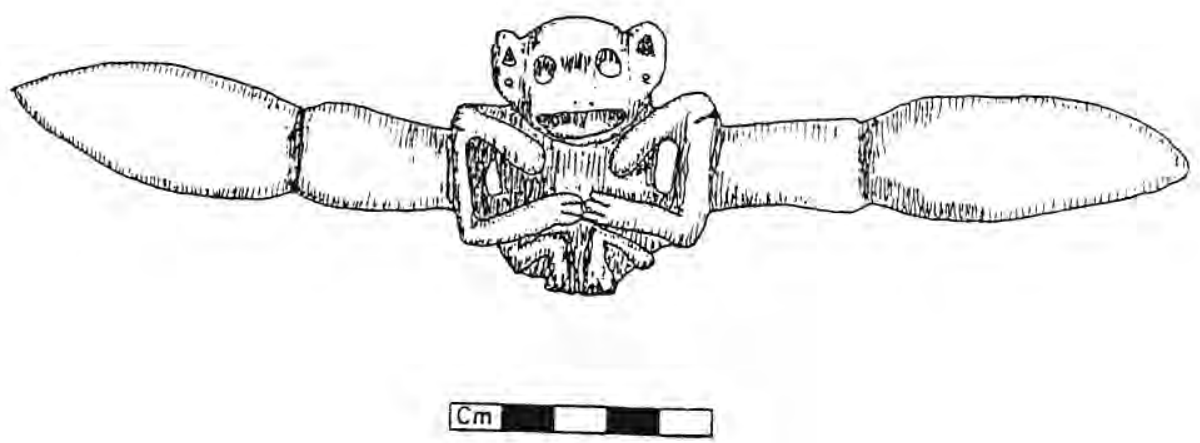

Figure 9 Double-bladed vomit spatula - Dominican Republic (after Kerchache 1994: 88-89) 
The anthropo/zoomorphic artefacts in my study originate only from the Greater Antilles and are so-called in twenty-six cases where features cannot be classified as either specifically human or animal or are combinations of both elements creating imaginary creatures (Fig. 3). Four are combined forms where the head of a bird is clearly on a human body, which I interpret as reflecting the duality of shamanistic movement between two spheres. In another, a crouched human figure metamorphoses into a dog, the god Opiyelgoubiran, who, echoing the mythology of the mainland jaguar, stalks the jungle at night (Caro Alvarez 1977). Nearly half the forty-eight duhos studied are in anthropo/zoomorphic form and are so similar that in some cases it could be presumed they originate from the same workshop.

Overall, occurring together as they do in the temporal record c. AD 1000 to 1500 , it is possible to say there is a continuity of stylistic imagery with the artefact categories of duhos and idols. The shapes in which these artefacts are made seem consistent across their various types and materials with certain shared symbols. Repetitive key component parts comprise the basis for their decoration. Surface decorations conform to repeated geometrical patterns, often of extreme complexity, incorporating symmetrical lines, triangles, circles, scrolls and dots. In some cases, closer inspection of these reveals that they contain other inverted abstract figures - representing the perceptual distortions associated with hallucinogen use.

A greater variation exists in the forms of the Caribbean vomit spatulas and inhaling bowls, where examples originate from much earlier dates and, as mentioned previously, have been found in different contexts from the preceding two categories.

The vomit spatulas reveal a greater variety in decoration and size, ranging from naturally-curving completely unadorned manati or shell spatulas, to those with simple line decorated blades and others of a more complex nature. This is possibly due to the fact that "everyone" used these and perhaps made their own in addition to the creation of élite examples. Among the latter, there exists a crossover of patterns and carvings bearing similar iconographic messages as the duhos, idols and inhaling tubes. My research shows that vomit spatulas also cover a wider date range; the earliest originating from Puerto Rico c. first century $\mathrm{AD}$ and continuing until the contact period. However, the majority (and some of the most elaborate) derive from the Dominican Republic and are recorded simply as "Taino" - implying the period AD 1000 to 1500 . While the simplest blade forms do come from the earlier dated sites on various islands, minimally decorated plain spatulate shapes have also been excavated from late dated contexts in Tortola and Puerto Rico.

Inhaling bowls are the only group of artefacts which I have studied of which more survive from the Lesser Antilles (24) than the Greater Antilles (12), and for which I have the largest number from the mainland with which to make a comparison (27). They occur within the longest date span in both Antillean areas, i.e, c. $100 \mathrm{AD}$ to contact period in the Lesser Antilles and c. 500 BC to contact period in the Greater Antilles.

In the Caribbean, the complete bowl of the vessel survives only in a minority of cases but from these and the other fragments, the forms are shown to vary from a shallow 
oval to a deeper rounded shape. On the mainland, all the twenty-seven vessels I have been able to examine are complete. In Costa Rica, the bowls of a number of inhaling vessels are plain and smaller in size than those from the Caribbean. The bowl shape is generally less open and shallow but has a rolled over rounded rim - a feature also found in Barbados. The inhaling vessels from Mexico take plain, anthropomorphic, zoomorphic and anthropo/zoomorphic forms.

The Caribbean yessels studied are all double spouted, with one exception (Fig. 1), whereas seven of the Costa Rican inhaling bowls known to me are single spouted, as are all but one of the Mexican examples studied. I know of only one example of a Mexican double spouted inhaling bowl (Furst 1974; 11). It has been proposed that these single spouted vessels suggest use as enema clysters (McGinnis 1999: pers. comm.); however, Mexican effigy figures clearly demonstrate the use of these vessels to be nasal.

Although anthropomorphic and zoomorphic forms are known, the majority of inhaling bowls in the Caribbean are plain. These are either devoid of incised decoration, although occasionally bearing the remains of brown or red staining or paint, or with decoration limited to a single perforation (possibly for suspension), a pinching in the shape at one end or an indentation in the base. Where decorations do occur these are generally lines incised around the rim of the bowl or at the spout/bowl junction.

Another form of decoration is a bulbous protuberance with a central pit which is fashioned on the outer side of the vessel, usually at the spout/base junction. Figure 2 shows these at all four "corners". Identical pitted protuberances are found on inhaling vessels from islands as far apart as Trinidad, Montserrat, Carriacou, St Vincent and Puerto Rico. However, this adornment is also to be found on a wide range of other ceramic artefacts which occur in the Lesser Antilles' Saladoid.

A consistency of form and decoration occurs on inhaling vessels over a long period in Puerto Rico, with the protuberances referred to above occurring on six vessels from the site of Sorce, La Hueca, three of which have been radiocarbon dated to produce dates of AD 5 - 425 and three to AD 1160 - 1545 (Narganes Storde 1991: 628-646). An element of controversy regarding site methodology and interpretation exists with regard to the La Hueca material, however (Oliver 1998).

On St Vincent these protuberances occur on the two vessels dated stylistically to AD $350-650$ but not on the two from that island dated to AD $700-1492$ which are undecorated and completely different. On Montserrat, the site from which two fragments with this patterning were retrieved is dated from BC 500 - AD 600 (Haviser 1997: 60-64). Unfortunately, no dates are ascribed to the complete vessel from Trinidad (Fig. 2) carrying this decoration, nor from Carriacou where, of the two partial vessels known to have originated from that island, one carries the pitted protuberances and one does not. The latter vessel is of similar shape and plain form to one found in Barbados which is also undated. 
A sharply angled plain red painted fragment from the front of a bowl is the only Puerto Rican bowl fragment ascribed the early date of BC 340 - AD 490 at TeclaGuayanilla; the others from this date and those dated to BC 160 - AD 870 (the next earliest date) from La Hueca are all single unconnected broken spouts (Narganes Storde 1991: 628-646).

Protuberances are also to be found at the same junction on the majority of the Costa Rican inhaling bowls (dated to c. BC $100-$ AD 500). On these vessels, they become flattened and are lacking the central pit - interpreted as stylised references to birds, representations of which are frequently found in Costa Rican archaeology.

It can be said that from general stylistic trends in Caribbean pottery, those which are fine-walled and of higher quality would be expected to be of an earlier date and derive from the Saladoid complex (Versteeg and Schinkel 1992: 72). This expectation is supported by the most elaborately shaped and decorated Caribbean inhaling bowls where dates are known (as quoted above).

\section{Change across time and space}

Clear differences exist between those artefacts which are dated to the later pre-contact period and can be linked together by a continuity of form and patterning across the various types and those which do not. These latter include the inhaling bowls but also some vomit spatulas. The vomit spatulas from the Lesser Antilles (which occur at the earliest dates) do not have the complex forms or patterns of those from the Greater Antilles.

Only the inhaling bowls reveal a linking of forms and patterns between the Lesser and Greater Antilles during the earlier Saladoid period. This ceases in the later period, with Puerto Rico alone having a (disputed) continuity of patterning on inhaling bowls retained into the later period. Stylistic echoes in Caribbean inhaling bowls can be found with much earlier dated ones from Costa Rica and Mexico. Certain decorative patterns are linked to those of the La Gruta complex dated to the second millennium $\mathrm{BC}$ in Venezuela, leading to the conclusion that a strong cultural continuity existed between the Venezuelan Saladoid and the much later Caribbean Saladoid, "holding true for decoration patterns, the way they were executed and the concepts behind the pottery making process" (Roosevelt 1980: 195 in Versteeg and Schinkel 1992: 72).

\section{Botany}

The hallucinogenic plants used in the cohoba ceremony are not known to us for a number of reasons. Firstly, the lack of palaeobotanical research in the Caribbean means that the botanical nature of the islands in the pre-contact period is uncertain. Secondly, there are no artefacts depicting the plants involved in the ritual. Finally, although the cronistas described the ceremony, the plant material involved was not clearly described and subsequent descriptions were confusing and, at times, contradictory. Las Casas mentions the sniffing of a powder through a forked tube from a dish on the head of an idol (Safford 1916: 547-562). Oviedo referred to tobacco as "being smoked by the Indians in order to lose their senses" and that it was this smoke which was inhaled through Y-shaped tubes (Safford 1916: 550). Ramon Pané referred to "this powder they draw up through the nose..." but Peter Martyr's 
account, which paraphrases Pané, adds "... an herb which they pound up and drink", not mentioning the forked tube. (My emphasis throughout.)

William Safford (Safford 1916) first suggested the seeds of Anadenanthera peregrina as the "cohoba snuff of ancient Haiti". A. peregrina, although not indigenous to the West Indies, is found today in second growth contexts in various islands of the Lesser Antilles, as well as Hispaniola, Puerto Rico and Jamaica. Wilbert translates a description of "the pod with lentil-shaped seeds" in Oviedo as fitting a description of the highly hallucinogenic seed pods of the Anadenanthera peregrina. Cohoba (coroba), however, is currently still in use as a designation for ritual tobacco use among the Winikina-Warao Indians of the Orinoco delta - an area from which Anadenanthera peregrina is absent (Wilbert 1987: 16-18).

In order to ascertain the identity of the hallucinogens involved there is an urgent need for the consistent application of archaeobotanical studies in the Caribbean to identify plant micro and macro remains and for the chemical analysis of residues from the artefacts to be undertaken as routes to determining the plant materials used in the cohoba ritual.

\section{Conclusions}

Originating from earlier dates, the inhaling bowls remain an enigma. They can be seen as precursors of a later and more complex ritual which involved the use of different paraphernalia. It is suggested that these later forms can be seen as transpositions of ideas brought by early migrants from South America, which perhaps adapted inhalation through ceramic inhaling bowls to a more formal and elaborate public ritual in the late pre-contact period, with distribution predominantly in the Greater Antilles. The complexity of many of these forms reflects craft specialisation which can be associated with sedentary, agricultural, hierarchical societies (Veloz Maggiolo 1977a: 5-6).

The link with early pottery forms from northern South America with those of Mesoamerica poses questions of cultural contact and/or migrations which have not yet been thoroughly addressed and could be answered with the identification of the hallucinogenic plant materials involved thus linking plants to people.

\section{Acknowledgements}

I should like to acknowledge the assistance I have received from the University of London Central Research Fund, the University College London Graduate School Research Projects and Equipment Fund and the Institute of Archaeology Awards in pursuing my research.

\section{References}

Alegria, R.E. 1951. The ballgame played by the aborigines of the Antilles. American Antiquity 16: 348-52.

Alegria, R.E. 1995. Apuntes sobre la vestimenta y los adornos de los caciques Tainos de las Antillas y de la parafernalia associeda a sus funciones magico- 
religiosas, in Alegria, R.E. and Rodriguez, M. (eds). Proceedings of the 15th International Congress for Caribbean Archaeology, San Juan de Puerto Rico, 1993: 295-309.

Allaire, L. 1997. The Lesser Antilles before Columbus, in Wilson, S.M. (ed.) The Indigenous People of the Caribbean. University Press of Florida: 20-28.

Anawalt, P.R. 1998. They Came to Trade Exquisite Things: Ancient West Mexican

- Ecuadorian Contacts, in Townsend, R.F. (ed.). Ancient West Mexico: Art and Archaeology of the Unknown Past. Chicago: Art Institute of Chicago: 233-249.

Arrom, J.J. 1980. Ramón Pané: Relacíon acerca de las Antiguedades de los Indios (4th edition). America Nuestra: Siglo Veintiuno.

Arrom, J.J. 1992. Fray Ramón Pané, Discoverer of the Taino People, in Java, R. and Spadaccini, N. (eds). Amerindian Images and the Legacy of Columbus. Minneapolis and London: University of Minnesota Press: 266-290.

Bourne, E.G. 1906. Columbus, Ramón Pané and the Beginnings of American Anthropology. Worcester: Reprinted from the Proceedings of the American Antiquarian Society.

Bruhns, K.O. 1994. Ancient South America. Cambridge: Cambridge University Press.

Caro Alvarez, J.E. 1977. Cemies y Trigonolitos. Barcelona: Artes Graficas Manuel Pareka.

Coe, M.D. 1988. Ideology of the Mayan Tomb, in Benson, E.P. and Griffin, G.G. (eds). Mayan Iconography. Princeton: Princeton University Press: 222-235.

Dacal Moure, R. and Rivero de la Calle, M. 1996. Art and Archaeology of PreColumbian Cuba. Pittsburgh: University of Pittsburgh Press.

Davis, D, and Goodwin, R.C. 1990. Island Carib Origins: Evidence \& Nonevidence. American Antiquity 55 (1): 37-48.

Drewett, P.L. 1998. Excavations at the prehistoric settlement site at Belmont, Tortola, British Virgin Islands 1996/97 An Interim Report. London: Institute of Archaeology, University College London.

Dubelaar, C.N. 1995. The Petroglyphs of the Lesser Antilles, the Virgin Islands and Trinidad. Amsterdam: Publications Foundation for Scientific Research in the Caribbean Region 135.

Fewkes, J.W. 1907. The Aborigines of Porto Rico and Neighbouring Islands, in 
Twenty-Fifth Annual Report of the U.S. Bureau of Ethnology to the Secretary of the Smithsonian Institution, 1903-04. New York and London: Johnson Reprint Corporation Reprinted 1970.

Furst, P.T. 1998. Shamanic Symbolism, Transformation, and Deities in West Mexican Funerary Art, in Townsend, R.F. (ed.). Ancient West Mexico: Art and Archaeology of the Unknown Past. Chicago: Art Institute of Chicago: 169-189.

Furst, P.T. and Coe, M.D. 1977. Ritual Enemas. Natural History 86 (3): 88-91.

Haviser, J.B. 1997. Settlement Strategies in the Early Ceramic Age, in Wilson, S.M. (ed.). The Indigenous People of the Caribbean. University of Florida Press: 59-69.

Honychurch, L. 1995. The Dominica Story: A History of the Island. London and Basingstoke: Macmillan Education Ltd.

Hulme, P. 1986. Colonial Encounters, London and New York: Methuen.

Jones, U. 1991. Metates and Hallucinogens in Costa Rica. Papers from the Institute of Archaeology 2: 29-34.

Keegan, W.F. 1992. The People Who Discovered Columbus. Florida: University Press of Florida.

Keegan, W.F. and Diamond, J. 1989. Creating the Guanahatabey (Ciboney): the modern genesis of an extinct culture, Antiquity 63, 239: 373-379.

Keen, B. (translated and annotated). 1959. The Life of the Admiral Christopher Columbus by his son Ferdinand. London: The Folio Society.

Kerchache, J. (ed.). 1994. L'Art des Sculpteurs Tainos, Chefs-d'Oeuvre des Grandes Antilles Précolombiennes. Paris; Musée du Petit Palais.

Labbe, A.J. 1986. Colombia before Columbus: The People, Culture and Ceramic Art of Prehispanic Colombia. New York: Rizzoli International Publications Inc.

Narganes Storde, Y. 1991. Secuencia cronologica de dos sitos arqueologicos de Puerto Rico (Sorce, Vieques y Tecla, Guyanilla), in Ayubi, E.N. and Haviser, J.B. (eds.). Proceedings of the Thirteenth International Congress for Caribbean Archaeology: Report of the Archaeological-Anthropological Institute of the Netherlands Antilles 9 (2): 628-646.

Oliver, J. 1997. The Taino Cosmos, in Wilson, S.M. (ed.). The Indigenous People of the Caribbean. University Press of Florida: 140-153. 
Oliver, J. 1998. The 'La Hueca Problem' in Puerto Rico \& the Caribbean: Old Problems, New Perspectives, Possible Solutions, in Hofman, C.L. and Hoogland, M.L.P. (eds.). Archaeological Investigations on St Martin 1993, The Sites of Norman Estate, Hope Estate \& Anse des Peres.

Paulsen, A.C. 1977. Patterns of Maritime Trade between South Coastal Ecuador and Western Mesoamerica, 1500 BC - AD 600, in Benson, E.P. (ed) The Sea in the Pre-Columbian World. Washington DC: Dumbarton Oaks Research Library and Collections: 141-160.

Porter Weaver, M. 1981. The Aztecs, Maya and Their Predecessors. London: Academic Press.

Rainey, F.G. 1940, Scientific Survey of Porto Rico and the Virgin Islands: XIII, 3. New York: New York Academy of Sciences.

Reichel-Dolmatoff, G. 1988. Goldwork and Shamanism. Columbia: Compana Litografica Nacional S. A.

Roach, C.N.C. 1935. Old Barbados. The Journal of the Barbados Museum and Historical Society 3 (1): 137-148.

Roe, P.G. 1993. Cross-media Isomorphisms in Taino Ceramics and Petroglyphs from Puerto Rico, in Proceedings of the $14^{\text {th }}$ Congress of the International Association for Caribbean Archaeology, Barbados 1991: 637-671.

Roe, P.G. 1997. Just Wasting Away: Taino Shamanism and Concepts of Fertility, in Taino - Pre-Columbian Art and Culture from the Caribbean. New York: The Monacelli Press Inc: 124-157.

Rouse, I. 1948. The West Indies, in Steward, J.H. (ed.). Handbook of South American Indians 4: the Circum-Caribbean Tribes. Washington DC: Bureau of American Ethnology Bulletin 143 (4): 507-546.

Rouse, I. 1992. The Tainos; Rise and Decline of the People who Greeted Columbus. New Haven and London: Yale University Press.

Safford, W.E. 1915. Identity of cohoba, the narcotic snuff of ancient Haiti, Journal of the Washington Academy of Sciences 6: 547-562.

Sauer, C.O. 1966. The Early Spanish Main. Berkeley and Los Angeles: University of California Press.

Schultes, R.E. and Hofmann, A. 1980. The Botany and Chemistry of Hallucinogens. Springfield, Illinois: Charles C. Thomas.

Siegel, P.E. 1997. Ancestor Worship and Cosmology among the Taino, in Taino: 
Pre-Columbian Art and Culture from the Caribbean. New York: The Monacelli Press Inc: 106-111.

Veloz Maggiolo, M. 1972. Arqueologia prehistorica de Santo Domingo. Singapore: McGraw-Hill Far Eastern Publishers (S) Ltd.

Veloz Maggiolo, M. 1977a. Indigenous Art and Economy of Santo Domingo. Santo Domingo: Ediciones Cohoba.

Veloz Maggiolo, M. 1977b. Acerca del sistema de aprendizaje en la sociedad indigena Antillana. Revista Dominicana de Antropologia e Historia 7: 7985 .

Versteeg, A.H. and Schinkel, K. 1992. The Archaeology of St Eustatius: The Golden Rock Site, in Publication of the St Eustatius Historical Foundation No. 2 Publication of the Foundation for Scientific Research in the Caribbean Region No. 131. St Eustatius/Amsterdam.

Wassen, S.H. 1965. The Use of some Specific Kinds of South American Indian Snuff and Related Paraphernalia. Göteborg: Etnografiska Museum. Etnologiska Studier 28.

Wilbert, J. 1987. Tobacco and Shamanism in South America. New Haven and London: Yale University Press.

Willey, G.R. 1971. An Introduction to American Archaeology, Vol 2, South America. Englewood Cliffs, New Jersey: Prentice-Hall.

Wilson, S.M. 1997. The Indigenous People of the Caribbean. Florida: University Press of Florida: 4-7. 